\title{
The Employment and Income of Female Informal Workers at The Construction Site of Himlam Projects, Tan Phong Ward, District 7, Ho Chi Minh City
}

\author{
Doan Van Thang \\ Faculty of Sociology \\ Ton Duc Thang University \\ Ho Chi Minh City, Vietnam \\ E-mail: thangdoanvan2020@gmail.com
}

Received: August II, 2020

Accepted: August 28, 2020

Online Published: September II, 2020

doi: 10.46281 /aijssr.v5i3.76I

URL: https://doi.org/I0.4628I/aijssr.v5i3.76I

\begin{abstract}
The issue of the employment and income of workers is always a topic that attracts the concerns of sociologists. This study aims to explore the life of female informal workers. The study was conducted at the construction site of Himlam projects, Tan Phong Ward, District 7, Ho Chi Minh City with the participant of 175 female workers and 77 male workers. The questionnaire and interview were employed to collect both quantitative and qualitative data. The findings of the study revealed that the current life of female migrant workers at the construction site of the Himlam project, Tan Hung Ward, District 7, Ho Chi Minh city was facing many difficulties. Their income was low. Also, they were not allowed to sign long-term or definite-term contracts. Therefore, many issues need to be addressed to improve the quality of life and employment of female migrant workers in industrial parks, especially at the Himlam construction site. The government should pay more attention to gender equality and enact policies to improve the living standards of female informal workers. The author expects that the study will partly contribute to the policy-making process in Vietnam.
\end{abstract}

Keywords: Employment, Income, Female Informal Worker, Construction Site.

\section{Introduction}

Informal and formal sectors exist as indispensable objectives, and they are subject to the influence of economic laws, socioeconomic development policies as well as legal systems at different levels depending on each nation.

According to sociologists, informal workers often work without a written labor contract relating to their work, and they only have a verbal agreement with the employer. Therefore, they are often subject to abuse and exploitation. They have to work regardless of the time, day and night, in hazardous and unprotected production environment, so it is easy for them to get sick and diseases. Thus, whether access to services, social security, or participation in the community, the informal economy workers are disadvantaged. The main characteristics of the informal workers are unstable employment, low incomes, and long working hours, no employment contracts or contracts with social insurance, health insurance, extra allowances, or other social benefits. Such employees are often trapped in a cycle of poverty, have limited capacity, knowledge, and assets that create social integration challenges. Besides, labor productivity and income of these groups of workers are low. According to the statistical report on informal employment published by the General Statistics Office and the Institute of Labor Science and Social Affairs in 2019, Vietnam has more than I8 million unofficial workers, accounting for $57.2 \%$ of the total non-agricultural employment and three fourth of the total jobs in the economy. The informal economy workers are defined based on unofficial jobs, that is, workers create their jobs, and they do not have labor contracts. They do not join social insurance, health insurance, and they do not receive a fixed salary. Also, according to the General Department of Statistics, the rate of informal workers without joining social insurance in Vietnam is up to $97.9 \%$, and only $0.2 \%$ join compulsory social insurance, and $1.9 \%$ join voluntary social 
insurance. Not to mention the fact that the average monthly salary of informal workers (VND 4.4 million) is lower than that of formal workers (VND 6.7 million) in all job positions (Ngoc, 2019).

In this paper, the author focuses on exploring employment and the income of female informal workers at the construction site of Himlam projects, Tan Phong ward, district 7, Ho Chi Minh city. The study attempted to address the two following research questions:

- What is the situation of the material and spiritual life of the female informal workers at the construction site of the Himlam project, Tan Phong Ward, District 7, Ho Chi Minh city?

- What are the solutions to improve the life of female informal workers?

\section{Brief Literature Review \\ 2.I Informal Economy}

Researchers have used various labels to refer to the "informal economy". Ferman and Ferman called it "the irregular economy" (Ferman \& Ferman, 1973). It has been called "the underground economy" by Simon and Witte (Simon \& Witte, 1982). Dilnot and Morris used the label "the black economy" (Dilnot \& Morris, I98I). Frey, Weck, and Pommerehne used the term "the shadow economy" (Frey, Weck, \& Pommerehne, I982). The term "informal economy" was first used in an International Labor study of Ghana in 1973.

There are also many definitions of the informal economy. Feige defined "informal economy" as all currently unregistered economic activities, which contributes to the official gross domestic product (Feige, 1989). According to Nguyen Hoai Son, the informal sector consists of all private non-agricultural businesses, without business registration and providing products and services for the market (Son, 2013). The Institute of Statistical Science has defined informal sectors as all businesses without a legal status and business registration, producing at least one or several products and services for sale or exchange and do not include agriculture, forestry, and fishery" (referred to as agriculture) (Son, 2013). Agricultural production and business activities do not include in this definition since there are differences between agricultural and non-agricultural activities in terms of seasonality, organizing labor, income levels, and research instruments in these two areas. Formal production households (with business registration) belong to the formal economic sector. Although there are different points of view, in general, the informal economic sector includes the area of operation of all production and business establishments without legal status, producing at least one or several products and services for sale or exchange without business registration (without a business license). In Vietnam, production, and business establishments operating in this area are mainly non-agricultural individual business and production groups and cooperative groups (Institute of Statistical Science, 2010).

\subsection{Informal Employment}

Informal economy workers and informal employment are considered as two different concepts with distinct content. The informal economy workers refer to those who hold an unofficial job while informal employment refers to a job. According to Hart, the term informal employment typically incorporates all economic activities that operate outside government rules, taxes, regulations, and monitoring (General Statistics Office and International Labor Organization, 2016). Portes defines informal employment as work performed in income-producing endeavors that run without formal wage arrangements (Hart, I973). Nguyen Hoai Son (2013) stated, "Informal employment consists of jobs in the informal sector without insurance and welfare"

According to ILO, informal employment is defined as employment without social issuance (especially compulsory social issuance) and an absence of at least a three-month labor contract (General Statistics Office and World Labor Organization, 2016).

\section{Research Methods \\ 3.I Participants}

The study was conducted at the construction site of the Himlam project, Tan Phong Ward, District 7, Ho Chi Minh city, with the participation of 252 migrant workers. Him Lam Kenh Te project is invested by Him Lam Trading Co., Ltd. The project is located in front of North-South Highway, near Kenh Te Bridge, in Tan Hung Ward, District 7, Ho Chi Minh City. It is only 3 $\mathrm{km}$ from Ben Thanh market and I km from Phu My Hung new urban area, located on the intersection of the main roads such as Nguyen Van Linh Avenue, Nguyen Thi Thap street, Khanh Hoi street, Le Van Luong street, thereby linking Districts I, 4, 7, Binh Chanh, and Nha Be District. 
The participants of the survey are classified into the following social groups:

Table I. Characteristics of the participants of the survey

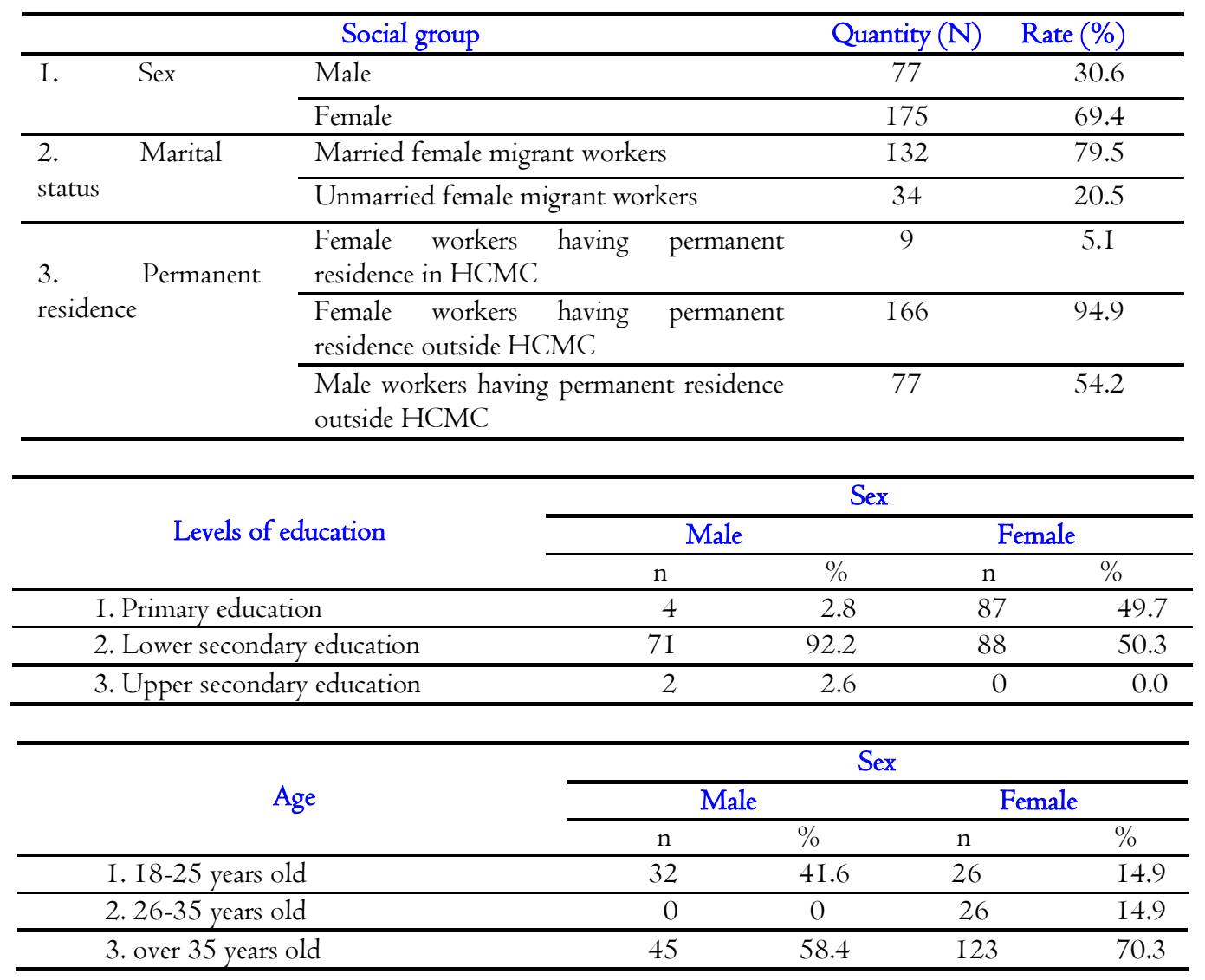

\subsection{Research Instruments}

The study employed two main instruments for collecting data, namely questionnaire for quantitative data and interviews for qualitative data. The questionnaire includes six parts: (i) employment - income; (ii) housing, means of living and cultural activities; (iii) working conditions and welfare; (iv) reproductive health care; (v) education for female migrant workers' children; (vi) information on the characteristics of the respondent

The author conducted eight in-depth interviews. The interview questions focused on the issues that were included in the questionnaire, especially the workers' opinions about the material and spiritual life of female migrant workers at the construction site of the Himlam project.

\subsection{Data Analysis}

Regarding data analysis procedures, for analyzing quantitative data collected from the questionnaire, descriptive statistics was employed through the use of SPSS version 22. Mean scores and standard deviation were calculated.

\section{Results}

Construction enterprises of the Himlam project tend to employ low-skilled and unstrained workers because of low labor costs that are an opportunity for workers, especially female workers, who migrate from rural areas to the cities to find a job to improve their life. The author's survey shows the overview of the lives of female immigrant workers at Himlam construction sites today, as follows: 


\section{I Employment}

Construction workers are unskilled laborers in the field of construction. In a survey conducted by the author, their employment consists of the work of the main workers and auxiliary workers. Men mainly work as main workers, while women only work as auxiliary workers. However, we also see five women as main workers as shown in the following table:

Table 2. The proportion of main and auxiliary workers by sex

\begin{tabular}{lcccc}
\hline \multirow{2}{*}{ Worker } & \multicolumn{5}{c}{ Sex } \\
\cline { 2 - 5 } & Male & \multicolumn{3}{c}{ Female } \\
\cline { 2 - 5 } & $\mathrm{n}$ & $\%$ & $\mathrm{n}$ & $\%$ \\
\hline Main worker & 54 & 70.1 & 5 & 2,9 \\
\hline Auxiliary worker & 23 & 29.9 & $\mathrm{I} 70$ & $97 . \mathrm{I}$ \\
\hline
\end{tabular}

The table shows that at the Himlam construction site, of 175 female workers, $97.1 \%$ are auxiliary workers, and $2.9 \%$ are the main ones. Main workers are responsible for building, painting, and ceiling installation. Auxiliary workers are usually in charge of the main tasks such as carrying water, mixing mortars, carrying bricks, etc.

In terms of age groups, Table 3 indicates that there is a difference between the two female worker groups with age from 18 to 25 years old and the older age groups. In the age group of I8 - 25 years, the percentage of main workers was higher than the other two age groups.

Table 3. The proportion of female workers by age

\begin{tabular}{|c|c|c|c|c|c|c|}
\hline \multirow{3}{*}{ The work } & \multicolumn{4}{|c|}{ Age group } & \multirow{2}{*}{\multicolumn{2}{|c|}{$\begin{array}{l}\text { Over } 35 \text { years } \\
\text { old }\end{array}$}} \\
\hline & \multicolumn{2}{|c|}{$\begin{array}{c}\text { From } 18 \text { to } 25 \\
\text { years old }\end{array}$} & \multicolumn{2}{|c|}{$\begin{array}{c}\text { From } 26 \text { to } 35 \\
\text { years old }\end{array}$} & & \\
\hline & $\mathrm{n}$ & $\%$ & $\mathrm{n}$ & $\%$ & $\mathrm{n}$ & $\%$ \\
\hline I. Main worker & 4 & $\mathrm{I} 5.4$ & 0 & 0.0 & $\mathrm{I}$ & 0.8 \\
\hline 2. Auxiliary worker & 22 & 84.6 & 26 & IO0.0 & 122 & 99.2 \\
\hline
\end{tabular}

Regarding gender groups, we can see the difference in employment between male and female migrant workers. In indicator I, for main workers, showed the male group accounted for the highest proportion of 70.1\%, compared to the female group with a rate of $1.7 \%$ (Table 4). It is a common belief that that the heavy work is for men; however, through this survey, it shows that hard work such as mixing lakes, carrying on, etc., are done by female migrant workers at the construction sites.

Table 4. Employment of migrant workers by sex

\begin{tabular}{|c|c|c|c|c|c|c|}
\hline \multirow{3}{*}{ Work } & \multicolumn{6}{|c|}{ Sex } \\
\hline & Male & & Female & & Total & \\
\hline & $\mathrm{n}$ & $\%$ & $\mathrm{n}$ & $\%$ & $\mathrm{n}$ & $\%$ \\
\hline I. Main worker & 54 & 70.1 & 3 & I.8 & 57 & 23.5 \\
\hline 2. Auxiliary worker & 23 & 29.9 & 163 & 98.2 & I86 & 76.5 \\
\hline Total & 77 & 100.0 & 166 & 100.0 & 243 & $\overline{100.0}$ \\
\hline
\end{tabular}

Chi-squared test with P-value $=.000$

To explore more deeply about this issue, the author interviewed a female auxiliary worker, and she stated, "I can earn very little by growing rice, so I decided to move to Ho Chi Minh city to work. The work is hard, but I can earn more money for our living". 
Regarding permanent residence, there is a relatively clear difference. In indicator I, for the main workers, the proportion of female workers having household registration in HCMC accounted for $22.2 \%$, compared to I.8\% of that outside HCMC. In indicator 2, for the auxiliary workers, the rate of female workers having household registration in HCMC accounted for only $77.8 \%$, compared to that outside HCMC of $98.2 \%$. (Figure I).

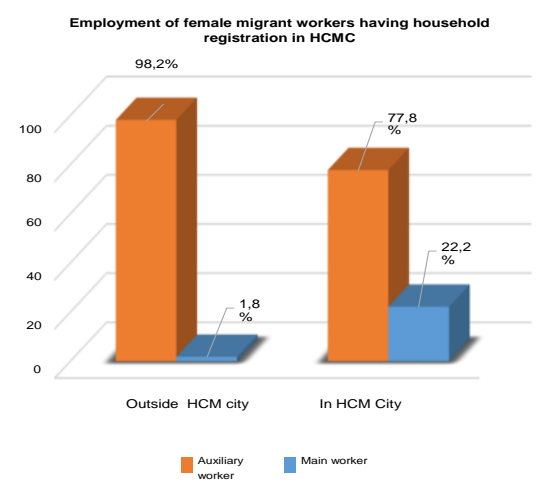

Figure I. The proportion of female migrant workers compared with female workers having permanent residence in HCMC

Thus, the jobs of female migrant workers are mostly auxiliary hard work such as carrying mortar, mixing mortar, etc. affecting their health and life.

\subsection{Labor contracts and Seniority}

\subsection{Labor Contract}

In recent years, enterprises in Vietnam have attained strong development that contributes to the increase of production capacity, and promotion of internal resources in socio-economic development, making a decisive contribution to the recovery, and economic growth, increasing export turnover, budget revenues and participating in effectively addressing social issues such as job creation, hunger eradication, and poverty reduction. To ensure the rights and obligations of employees in enterprises, our State has played a crucial role in the implementation of social policies for workers. So far, the State has issued many types of documents regulating the enforcement of social policies for workers, according to the process of developing the legal system. However, due to specific characteristics of labor at Himlam construction sites, no workers had an indefinite- term labor contract or labor contract with the term from 12 to 36 months. Only $25.5 \%$ of the workers had a seasonal contract, of which the rate of male migrant workers accounted for $19.5 \%$, and female migrant workers account for $28.3 \%$. In this type of contract, the proportion of female migrant workers accounted for more than male migrant workers. However, without any labor contract (working day-to-day work), the percentage of women was much higher than that of men (Figure 2).

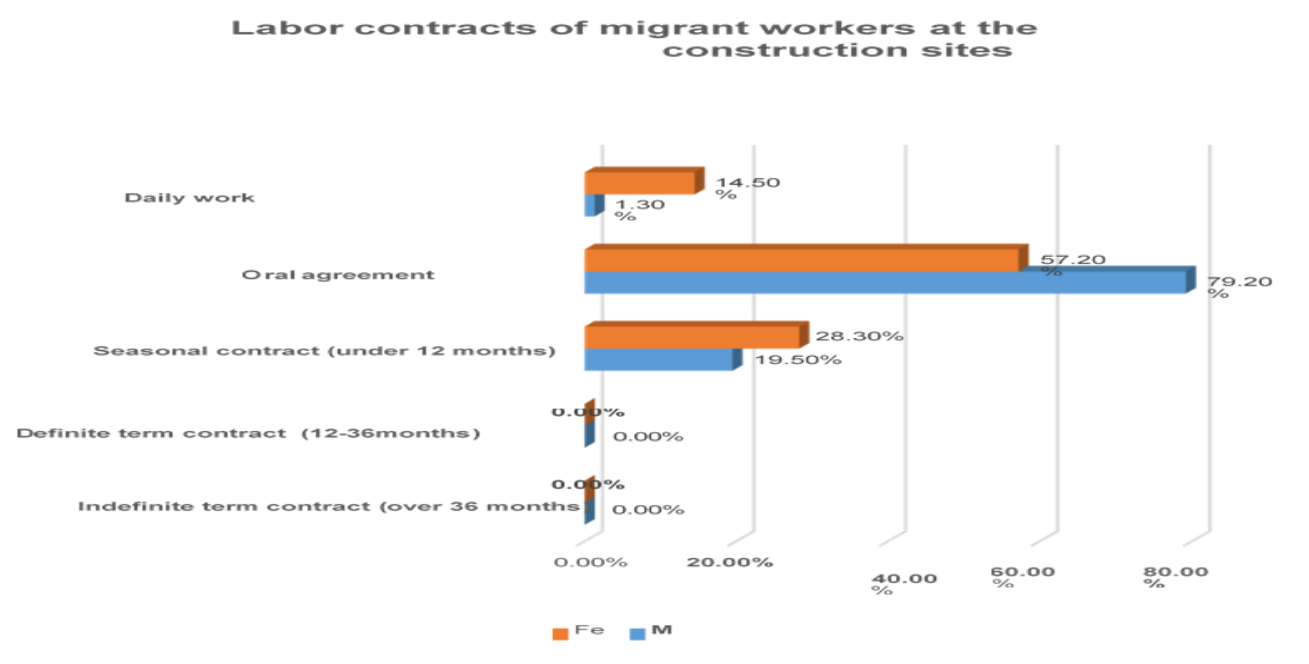

Figure 2. The proportion of female migrant workers and male migrant workers by labor contracts 
Seasonal contracts and oral agreement accounted for the highest proportions because of the typical characteristics of the jobs.

When the author interviewed a male manager at Himlam construction sites, he stated: "If the project takes only 4 or 5 months to complete, we will choose the contract forms such as verbal agreement or day-labor".

The data of the survey show a connection between labor contract indicators and working time. Those who work for two years or less have a higher rate of daily work than the group with more than two years of employment and a higher proportion of seasonal contracts (See Table 5).

Table 5. Types of labor contracts signed by migrant workers at the construction sites of Himlam project

\begin{tabular}{lcc}
\hline \multicolumn{1}{c}{$\begin{array}{c}\text { Types of labor } \\
\text { contracts }\end{array}$} & $\begin{array}{c}\text { Less than 2 } \\
\text { years }\end{array}$ & $\begin{array}{c}\text { Over } \\
\text { years }\end{array}$ \\
\hline \multicolumn{1}{c}{$\begin{array}{l}\text { An indefinite term contract } \\
\text { (or over 36 months) }\end{array}$} & $\%$ & $0.00 \%$ \\
\hline $\begin{array}{l}\text { Definite term contract (between } \\
\text { I2 months and 36 months) }\end{array}$ & $0.00 \%$ & $0.00 \%$ \\
\hline $\begin{array}{l}\text { A seasonal contract (under I2 } \\
\text { months) }\end{array}$ & $33.30 \%$ & $22.00 \%$ \\
\hline Verbal agreement & $50.70 \%$ & $70.20 \%$ \\
\hline Day-labor & $16.00 \%$ & $7.70 \%$ \\
\hline
\end{tabular}

Chi-squared test with P-value $=.000$

The signing of labor contracts and collective bargaining agreements is one of the basic requirements for enterprises in all types of businesses, including State-owned and private ones, which reflected in a detailed and complete manner in the legal documents issued by the State. However, most of the companies at the construction sites today do not have any organizations to protect the rights of workers. A 39-year-old builder said, "Her company does not have any labor union representative, so it is difficult to make the company fulfill its commitment." It seems that for migrant workers, the immediate priority is the need to find a job that generates income rather than concern about policies and labor contracts. Ms. L., a 28-year-old female migrant worker stated, "We are mostly from the countryside, with little understanding and no interest in labor contracts, getting hired by the company and having a job are happy."

\subsubsection{Seniority}

Working time to calculate severance allowance is the total time that workers work for their employers under labor contracts (including oral one). Through the author survey, this can be seen in Table 6 as follows:

Table 6. Working seniority of female migrant workers at the construction site by marital status:

\begin{tabular}{|c|c|c|c|c|c|c|}
\hline \multirow{3}{*}{ Seniority } & \multicolumn{4}{|c|}{ Marital status } & & \\
\hline & \multicolumn{2}{|l|}{ Married } & \multicolumn{2}{|l|}{ Single } & \multicolumn{2}{|c|}{ Total } \\
\hline & $\mathrm{n}$ & $\%$ & $\mathrm{n}$ & $\%$ & $\mathrm{n}$ & $\%$ \\
\hline I. Less than 6 months & 0 & 0.0 & 0 & 0.0 & 0 & 0.0 \\
\hline 2. 6 months - less than I year & 9 & 6.7 & 0 & 0.0 & 9 & 5.4 \\
\hline 3. I-2 years & 36 & 26.9 & II & 34.4 & 47 & 28.3 \\
\hline 4. 3-4 years & 0 & 0.0 & 9 & 28.10 & 9 & 5.4 \\
\hline 5. more than 5 years & 89 & 66.4 & $\mathrm{I} 2$ & 37.5 & IOI & 60.8 \\
\hline Total & 134 & 100.0 & 32 & 100.0 & 166 & 100.0 \\
\hline
\end{tabular}


At present, workers working for companies at Himlam construction site for more than five years accounted for the highest proportion of $58.3 \%$, compared to $28 \%$ working for I-2 years, $5.4 \%$ working for six months to less than one year, and $5.4 \%$ working for $3-4$ years, and no worker working for less than six months.

Regarding marriage status, Table 4-5 also shows that there is a difference between married and unmarried groups. In indicator 5, the proportion of the married group accounted for $66.4 \%$, higher than the unmarried group that represented $37.5 \%$. In indicators 3 and 4 , the rate of unmarried female groups accounted for $34.4 \%$ and $28.1 \%$, while married female groups represented $26.9 \%$ and $0 \%$. The reason for a higher proportion of married female group at the construction sites is that female workers often leave their hometown with their husband to find a job in cities. A female 39-year-old worker stated, "I have been working at this construction site for six years. It is hard work, so many female workers can only work for only a few months or some years and try to find another job”. And a male 37-year- old worker affirmed, "This is manual hard work so many women cannot bear it. Moreover, they have to look after their children, so they have to find a more suitable job."

Regarding household registration, in indicator 2,3, and 4, the proportion of female workers with household registration in the provinces outside Ho Chi Minh city was lower than that with household registration in Ho Chi Minh city. In indicator 5, with seniority of over five years, the rate of female workers with household registration in Ho Chi Minh City accounted for $44.4 \%$, lower than that with the household registration in the provinces representing $58.3 \%$. The reason for this issue may be the typical characteristics of these jobs. The author interviewed a female 39-year-old worker, and she answered, "I am reluctant to come here to earn money to support my children. When my children finish college, I will return to my hometown".

\subsection{Job Stability}

Income is proof of whether the job is stable or not. Through a survey of 175 female workers, including 166 female migrant workers at the Himlam construction sites, the results are shown in Table 7 as follows:

Table 7. Job stability of female migrant workers by marital status

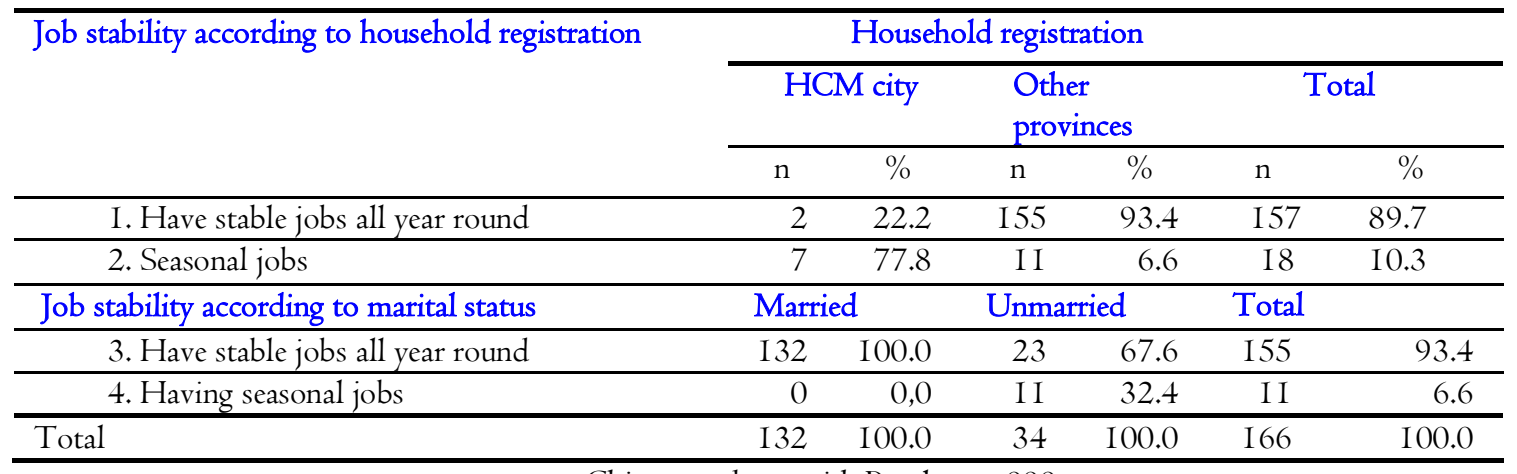

Chi-squared test with P-value $=.000$

The table shows that of 175 female workers at Himlam construction sites, the proportion of workers have stable jobs all year round accounted for $89.7 \%$ and $10.3 \%$ of them doing seasonal jobs.

Concerning the marital status of female migrant workers at the construction site, the table indicates that there is a big difference between the unmarried group and the married one. In indicator I, having stable jobs all year round, the rate of married workers accounted for $100 \%$ while the proportion of unmarried represented $67.6 \%$. In contrast, having seasonal work, the percentage of unmarried groups accounted for $32.4 \%$, while the rate of the married group made up $0 \%$. This figure is reasonable. Since the author interviewed a 40-year-old female worker, she answered, "I want a stable work, because it helps to generate a stable income to support my children and my family." A 28 -year-old female worker stated, "Due to hard work, a lot of female workers quit their work."

Regarding household registration, there is a difference between female workers having household registration in Ho Chi Minh City and other provinces. In indicator I, having jobs all year round, the proportion of female workers with household registration in other provinces accounted for $93.4 \%$, compared to the rate of female workers with household registration in HCMC representing $22.2 \%$. On the contrary, in indicator 2, having seasonal jobs, the proportion of the group having household registration in HCMC made up $77.8 \%$, higher than the group in other provinces representing 6.6\%. Regarding sex, there is also a difference between male and female migrant workers in the stability of jobs. In indicator I, having jobs all year round, the proportion of female workers accounted for $93.1 \%$, lower than that of male workers at $98.7 \%$. In indicator 2 , having 
seasonal jobs, the percentage of female workers made up $6.9 \%$ while the rate of male workers represented I.3\%. Considering this issue, the author interviewed a 42-year-old female worker, and she answered: "I left Soc Trang to come here to find a stable job to support my children."

\subsection{Income and Spending}

\subsection{Income}

Currently, the total income of the worker includes contractual wages, overtime pay (hourly labor), toxic money, attendance allowances, petrol allowances, housing, electricity, and water allowances. The results of the survey are shown in the table follows:

Table 8. Monthly income of the migrant workers by sex

\begin{tabular}{|c|c|c|c|c|c|c|}
\hline \multirow{3}{*}{ The total income } & \multicolumn{6}{|c|}{ Sex } \\
\hline & \multirow{2}{*}{$\frac{\text { Male }}{\mathrm{n}}$} & \multicolumn{3}{|c|}{ Female } & \multicolumn{2}{|c|}{ Total } \\
\hline & & $\%$ & $\bar{n}$ & $\%$ & $\mathrm{n}$ & $\%$ \\
\hline \multirow{2}{*}{$\begin{array}{l}\text { I. From } 5.5 \text { million to } 7 \text { million VND } \\
\text { per month }\end{array}$} & 3 & 3.9 & 6 & 38.0 & 6 & 27. \\
\hline & & & 3 & & 6 & 2 \\
\hline \multirow{2}{*}{$\begin{array}{l}\text { 2. From 7.I million to } 9 \text { million VND } \\
\text { per month }\end{array}$} & 5 & 6.5 & 8 & 52.4 & 9 & 37. \\
\hline & & & 7 & & 2 & 9 \\
\hline 3. Form 9.I million to 13.9 million & 69 & 89.6 & $\mathrm{I}$ & 9.6 & 8 & 35. \\
\hline $\begin{array}{l}\text { 3. Form } 9.1 \text { million to } 13.9 \text { million } \\
\text { VND per month }\end{array}$ & & & 6 & & 5 & 0 \\
\hline 4. The average of the income & & II5 & & 8,915 & & ,452 \\
\hline
\end{tabular}

Looking at the table more closely, one can see that there is a difference between the income of male and female workers at Himlam construction sites. The majority of male workers have an income of over 9 million Vietnam dong per month, accounting for $89.6 \%$. The proportion of female workers with a wage of more than 9 million Vietnam dong per month only made up $9.6 \%$. The rate of female workers with the income from 7.I million to 9 million Vietnam dong accounted for $52.4 \%$, and the percentage of female workers with an income of less than 7 million $\mathrm{VN}$ dong represented $38 \%$.

It is understandable since female workers mostly do auxiliary work. The average income of the main worker is $13,028,070$ Vietnam dong per month, while the average income of the auxiliary worker is 7,805,376 Vietnam dong per month. It can be seen in figure 3 as follows:

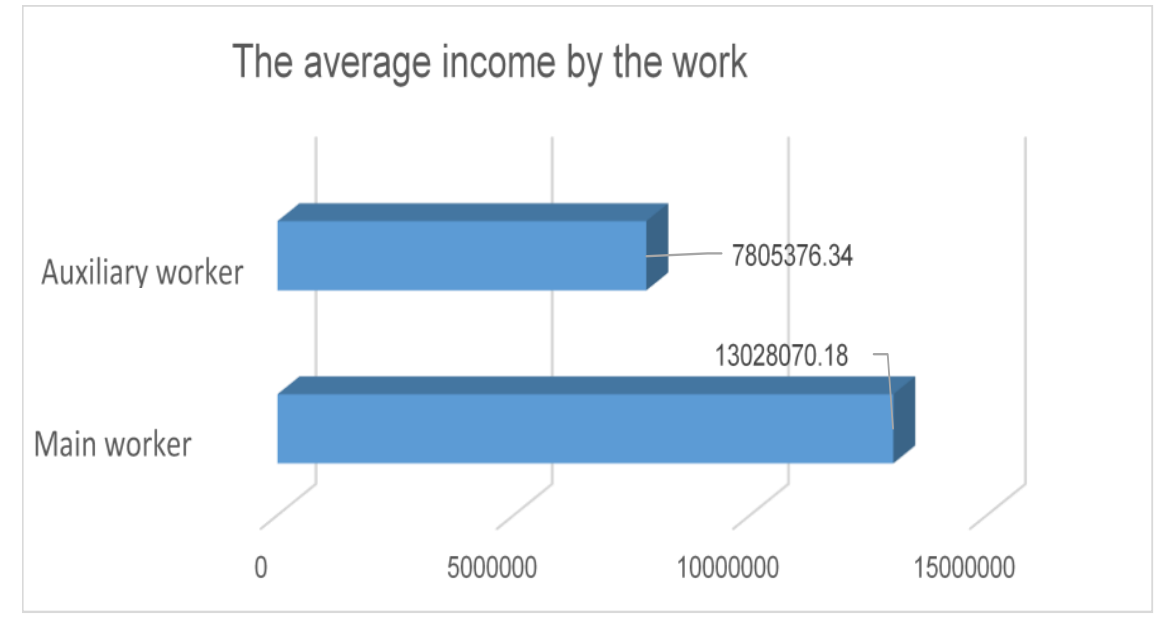

Chi-square test with P-value $=0.000$

Figure 3. The average income by the work

Concerning household registration, there is a difference between the income of female workers with household registration in Ho Chi Minh city and other provinces. Female migrant workers had a lower income than female workers with household registration in Ho Chi Minh city. That is because the proportion of female workers in Ho Chi Minh city doing main 
work accounted for $22.2 \%$, while the rate of female workers with household registration in other provinces doing main work made up only $1.8 \%$. The income of female migrant workers is usually lower than that of the other social groups. The total income of female migrant workers came from the following sources:

Salary income: The total income of the workers came from different sources including their salary. The salary of a worker is a value in cash or other equivalent forms of money due to an agreement between the two parties in a labor contract, and it is paid according to labor productivity, quality, and work efficiency. Salary income plays a crucial role in improving the living standards of the worker and reproducing the workers' labor force. The results of the survey of the author about salary income is shown in the following table:

Table 9. Salary income of migrant workers at the construction site by marital status

\begin{tabular}{|c|c|c|c|c|c|c|}
\hline \multirow{3}{*}{ Salary income } & \multicolumn{6}{|c|}{$\begin{array}{c}\text { Marital } \\
\text { status }\end{array}$} \\
\hline & \multicolumn{2}{|c|}{ Married } & \multicolumn{2}{|c|}{ Unmarried } & \multicolumn{2}{|c|}{ Total } \\
\hline & $\mathrm{n}$ & $\%$ & $\mathrm{n}$ & $\%$ & $\mathrm{n}$ & $\%$ \\
\hline I. From 4 to 7 million $\mathrm{VN}$ dong/month & 130 & 98.5 & $\begin{array}{l}2 \\
2\end{array}$ & $\begin{array}{l}64 . \\
7\end{array}$ & $\begin{array}{r}15 \\
2\end{array}$ & $\begin{array}{l}9 \mathrm{II} . \\
6\end{array}$ \\
\hline 2. From 7.I to I0.5 million VN dong/month & 2 & 1.5 & $\begin{array}{l} \\
2 \\
\end{array}$ & $\begin{array}{l}35 . \\
3 \\
\end{array}$ & I4 & $\begin{array}{l}8 . \\
4\end{array}$ \\
\hline Total & $\mathrm{I} 32$ & 100.0 & $\begin{array}{l}3 \\
4\end{array}$ & $\begin{array}{l}\text { I00. } \\
0\end{array}$ & 166 & $\begin{array}{l}\text { I00. } \\
0\end{array}$ \\
\hline
\end{tabular}

Chi-square test with P-value $=0.000$

According to table 9, the proportion of the female workers at Himlam construction sites with the income from 4 million to 7 million VND accounted for 91.6\% while the rate of female workers with the income from 7.I million to I0.5 million VND made up only $8.4 \%$.

Regarding marital status, Table 9 also shows that there is a difference between married and unmarried female workers. In indicator 1 , from 4million to 7 million VND, the married group accounted for the majority of $98.5 \%$ compared to the unmarried group representing $64.7 \%$. Meanwhile, in indicator 2, the unmarried group accounted for $35.3 \%$, while the married group made up 1.5\%. Finding out about this issue, the author interviewed Ms. A, a married worker, and she said, "We are auxiliary workers, so this salary level is quite good, and the job is regular" (Female, 40 years old). An unmarried female worker named L said: "My income is higher than other female workers' because my husband taught me how to build houses, so they paid more for me." (Female, 27 years old);

Regarding sex, there is a difference between the male and female migrant workers. In indicator I, with the income from 4 million to 7 million VND, the proportion of female workers accounted for 91.6\%, higher than the rate of the male group, which only represented I4.3\%. Meanwhile, in indicator 2, from 7.I million to I0.5 million, the male group made up $85.7 \%$, the female group accounted for $8.4 \%$. The author interviewed a 37 -year-old male worker at the construction site, and he stated: "Women from the western provinces in Vietnam often follow their husband to come here to work and their salary is lower than the main workers."

Table I0. Salary income of migrant workers at the construction site by sex

\begin{tabular}{|c|c|c|c|c|}
\hline \multirow{3}{*}{ Salary income } & \multicolumn{3}{|c|}{ Sex } & \multirow{3}{*}{$\frac{\text { Female }}{\%}$} \\
\hline & \multicolumn{3}{|c|}{ Male } & \\
\hline & $\mathrm{n}$ & $\%$ & $\mathrm{n}$ & \\
\hline $\begin{array}{l}\text { I. From } 4 \text { million to } 7 \text { million VND/ } \\
\text { month }\end{array}$ & II & $\begin{array}{l}\mathrm{I} 4 . \\
3\end{array}$ & 152 & 91.6 \\
\hline $\begin{array}{l}\text { 2. From } 7.1 \text { million to I0.5 million VND/ } \\
\text { month }\end{array}$ & 66 & $\begin{array}{l}85 . \\
7\end{array}$ & $\mathrm{I} 4$ & 8.4 \\
\hline
\end{tabular}

Chi-square test with P-value $=0.000$ 
Regarding the household registration, there is a difference between the group of female workers with household registration in HCMC and other provinces. In the indicator I, from $4 \operatorname{Tr}$ to $7 \operatorname{Tr} V N D$, the percentage of female group with household registration in other provinces accounted for $91.6 \%$, higher than the rate of the female group in HCMC representing 66.7\%. Meanwhile, in indicator 2, from VND 7.I to I0.5 million VND, the proportion of female group with household registration in HCMC accounted for $33.3 \%$, higher than the rate of the women in other provinces, which made up $8.4 \%$ (see Table I2 in Appendix I). In this regard, Ms. Q, a 35-year-old worker with the household registration in Ho Chi Minh City said: "We do a daily work, and the workday pay is usually higher, but the work is often not stable." Ms. H, a 3I-year-old worker stated, "The workdays of main workers depend on whether they are skillful or unskillful workers. Their workdays pay is 300,000 VND, much higher than that of their assistants". Thus, with low wages, female migrant workers are still satisfied since they have better jobs and income now than the time they live in their hometown without jobs. Everett S. Lee called these factors "gravity". These are employment opportunities for migrants and disparities in living standards due to uneven development leading to differences in living standards across regions.

Overtime income: Overtime pay of workers working at the Himlam site accounted for 5.67\% of the total income of female workers, which is lower than male workers making up I2.36\%. However, of migrant workers, the overtime income of the unmarried was higher the average level of 785,294 VND per month. Married people had an overtime income of 360,606 VND (Table II)

Table I I. Average overtime income by marital status

\begin{tabular}{crrr}
\hline Marrige status & Mean & Std. Deviation \\
\hline I. Married & $360,606.06$ & I32 & 490327.446 \\
\hline 2. Unmarried & $785,294.12$ & 34 & 597536.535 \\
\hline Total & $447,590.36$ & I66 & 540224.623 \\
\hline
\end{tabular}

In this regard, Ms. M, a 28-year-old unmarried worker, said: "We do not have children so we can work overtime, but those who are married, the women have to pick up their children, so their husbands work overtime."

Regarding the household registration, there is a difference of overtime income between the group of female workers with household registration in HCMC and other provinces (Table I2).

Table I2. Average overtime income by household registration

\begin{tabular}{cccc}
\hline $\begin{array}{c}\text { Household } \\
\text { registration }\end{array}$ & Mean & & Std. Deviation \\
\hline I. HCMC & $\mathrm{I}, 244,444.44$ & 9 & 510174.262 \\
\hline 2. Other provinces & $447,590.36$ & $\mathrm{I}$ & 540224.623 \\
& & 6 & \\
\hline Total & 6 & $\mathrm{I}$ & 565569.304 \\
& $488,571.43$ & 7 & \\
\hline
\end{tabular}

ANOVA test with $\mathrm{P}=0.000$

The reason is that the female workers who have household registration in Ho Chi Minh City have more time when their children have been taken care of by other members of the family. Ms. Q., a 35-year-old worker said: "My children have been picked up and taken care of by their grandparents, so I have time to work overtime." The overtime income of the female group was much lower than that of the male group. The author interviewed a 39-year-old female worker named M., and she answered: "We only do auxiliary jobs, so when they work overtime; they pay very low, only 30,000 VND per hour".

Although working in an unfavorable work environment, workers at the Himlam construction site were not entitled to hazardous money, diligent allowances, and allowances for petrol and vehicles. However, the company offered housing, electricity, and water supply for their workers with the amount of I million VND per month to improve their living standards. 


\subsubsection{Spending}

Table I3 below indicates that the proportion of female workers at the Himlam construction site spending 5 million VND per month accounted for $99.4 \%$, much higher than that of female workers spending form 5 million to 8.6 million VND per month. It is apparent that the CN people are very economical in spending, they mainly spend less than 5 million VND, they mostly spend on meals, medical care, and children care. Regarding social groups, namely marriage, sex, and household, there was no difference in expenditure level in the month.

Table 13. Expenditure levels of female migrant workers by marital status

\begin{tabular}{|c|c|c|c|c|c|c|}
\hline \multirow{3}{*}{ Spending } & \multicolumn{6}{|c|}{$\begin{array}{c}\text { Marriage } \\
\text { status }\end{array}$} \\
\hline & \multicolumn{2}{|c|}{ Marred } & \multicolumn{2}{|c|}{$\begin{array}{c}\text { Unmarried } \\
\text { đình }\end{array}$} & \multicolumn{2}{|c|}{ Total } \\
\hline & $\mathrm{n}$ & $\%$ & $\mathrm{n}$ & $\%$ & $\mathrm{n}$ & $\%$ \\
\hline I. Less than 5 million VND/month & 132 & 100 & 33 & 97.1 & 165 & 99.4 \\
\hline 2. From 5 to 8.5 million/ month & 0 & 0.0 & $\mathrm{I}$ & 2.9 & $\mathrm{I}$ & $\overline{0,6}$ \\
\hline Total & $\mathrm{I} 32$ & 100 & 34 & 100 & 166 & 100 \\
\hline
\end{tabular}

However, there are differences among the female workers having children with them and the ones who do not have children with them or unmarried workers. The average monthly expenditure of those who have children with them is 5,478,947 VND, while those who have no children with them or are single, their average monthly payment is 2,66I,328 VND.

Table I4. The average monthly spending by the group having children accompanying and the one without having children accompanying

\begin{tabular}{cccc}
\hline & Mean & N & Std. Deviation \\
\hline I. Having no children accompanying or being unmarried & $2,661,328.13$ & $\mathrm{I} 28$ & 954500.629 \\
& & & \\
\hline 2. Having children accompanying & $5,478,947.37$ & 38 & 2385758.182 \\
\hline Total & $3,306,325.30$ & $\mathrm{I} 66$ & $\mathrm{I} 840497.065$ \\
\hline
\end{tabular}

ANOVA test with $\mathrm{P}=0.000$

If we calculate the income of female migrant workers compared to their spending, they still have a little monthly to send home to support their children and parents. If the average balance from the total income/month minus total spending/month is the average balance of VND 4,372,590, of which the amount of female married workers is less than that of female single workers (Table I5).

Thus, with the goal of leaving home to earn money to send back to support their family, the female migrant workers had to save money. The amount of money you save depends on their state of being married or single.

Table 15. Difference between income and expenditure by marital status

\begin{tabular}{crrr}
\hline Marital status & Mean & $\mathrm{n}$ & \multicolumn{1}{c}{ Std. Deviation } \\
\hline I. Married & $3,998,134$ & $\mathrm{I} 34$ & 2399619.383 \\
\hline 2. Unmarried & $5,940,625$ & 32 & 1923808.282 \\
\hline Total & $4,372,590$ & $\mathrm{I} 66$ & $2434646.12 \mathrm{I}$ \\
\hline
\end{tabular}

\section{Conclusion and Recommendations}

To sum up, in this paper, the author has studied in-depth to explore different aspects of the reality of the employment and income of female informal economy workers at the Himlam construction site. Their jobs are now quite stable. The proportion of female workers with stable jobs all year round accounted for 93.1\%. However, the group of female migrant workers was still 
not allowed to sign long-term or definite-term contracts, but verbal and casual ones. The salary income of the female migrant workers only range from 4 million to 7 million VND per month. Compared with the spending level, female migrant workers can only save a little money to send home to support their families.

From the above situation, many issues that need to be addressed to further improve the quality of life and employment of female migrant workers in industrial parks and especially at the Himlam construction site. The Party, State, agencies, and authority should pay more attention to the issue of gender equality in guidelines and plans for socio-economic development and in legal documents and directions to attain gender equality in employment and social life to continue fulfilling well the goals of gender equality and the development of women in the spirit of Resolution II-NQ / TW of The Politburo on women's employment in the period of stepping up industrialization and modernization of the country. Workers are a particularly important part of the population in creating the majority of GDP, and a fundamental factor in the cause of industrialization, industrialization, and modernization of the country. The State and enterprises should care about the employment and the income of female migrant workers. Enterprises also need to have the guidance to improve their life, ensure their working health, and support the legitimate aspirations of workers, especially female workers.

\section{References}

Dilnot, A. \& Morris, C. (I98I). What do we know about the black economy in the United Kingdom?. Fiscal Studies, 2, I63179.

Frey, B., Weck, H., \& Pommerehne, W. (I982). Has the shadow economy grown in Germany. An exploratory study. Review of World Economics, II8, 499-524.

Feige, E. L. (1989). The Underground Economies. Tax Evasion and Information Distortion. Cambridge: Cambridge University Press.

Ferman, P., \& Ferman, L. (1973). The structural underpinning of the irregular economy. Poverty and Human Resources Abstracts, 8, 3-I7.

General Statistics Office and International Labor Organization. (2016). Unofficial Labor Report 20I6, Hong Duc Publishing House, p. 4.

General Statistics Office and World Labor Organization. (2016). Unofficial Labor Report 20I6, Hong Duc Publishing House, p.3

Hart, K. (1973). Informal Income Opportunities and Urban Employment in Ghana. Journal of Modern African Studies, $I I(\mathrm{I}): 6 \mathrm{I}-89$.

Institute of Statistical Science. (2010). Overview of the results of statistical surveys of the informal sector in Vietnam and some recommendations on information management of labor market and human resource development.

Ngoc, D. (2019). Informal Labor: Disadvantages in Access to Social Security Services. Retrieved from http://baodansinh.vn/lao-dong-phi-chinh-thuc-thiet-thoi- in-need-for-service-from-living-from-time-96937.htm

Portes, A., \& Walton, J. (I98I). Unequal exchange and the urban informal sector. Labor, Class and the International System. Alejandro Portes and John Walton, eds, 67-I06.

Simon, C., \& Witte, A. (1982). Beating the system: The underground economy. Boston: Auburn House Publishing Company.

Son, N. H. (2013). Informal sector in developed countries. Vietnam Journal of Social Sciences, IO(7I), p 89.

\section{Copyrights}

Copyright for this article is retained by the author(s), with first publication rights granted to the journal. This is an open-access article distributed under the terms and conditions of the Creative Commons Attribution license (http://creativecommons.org/licenses/by/4.0/). 